\title{
A ordem mundial e o Brasil
}

\author{
LUIZ A. P. SOUTO MAIOR*
}

\section{A busca de uma ordem mundial}

O século XX assistiu a um processo de mundialização sem precedentes dos mais diversos aspectos da vida quotidiana, antes percebidos como questões essencialmente nacionais. Ampliou-se assim o próprio conteúdo das relações internacionais e, conseqüentemente, percebeu-se a necessidade de um disciplinamento mais abrangente - em termos geográficos e substantivos - de tais relações. As dúvidas e divergências em torno do assunto tinham menos a ver com a noção mesma de uma ordem mundial do que com a sua forma. Em última análise, que aspectos da atividade dos Estados estariam sujeitos a alguma disciplina, que normas seriam estabelecidas, quem delas se beneficiaria e quem controlaria a sua aplicação. Tais questões, ainda não resolvidas de forma satisfatória, continuam no centro do debate relacionado com o estabelecimento de uma ordem mundial justa e democrática.

O processo de efetivo balizamento da conduta externa dos Estados tomou particular impulso a partir da II Guerra Mundial, e inicialmente teve como principal objeto os aspectos mais tradicionais das relações internacionais.

Num mundo que, em pouco mais de três décadas, fora vitimado pelas duas guerras mais sangrentas e destrutivas da história da humanidade, formou-se, entre os líderes das grandes potências, a consciência de que era preciso encontrar meios de evitar a repetição de cataclismas semelhantes. Em tais circunstâncias, era natural que, ainda durante a II Guerra Mundial, os Estados Unidos, como maior potência econômica e militar, tomasse a iniciativa de promover o estabelecimento de um sistema normativo capaz de disciplinar a conduta internacional dos Estados, tanto no terreno político como no econômico. Tal desiderato, louvável em tese, suscitava, na prática, problemas de dificílima solução. Para as grandes potências, o desafio era, em última análise, estabelecer um sistema capaz de evitar conflitos armados entre elas sem, porém, comprometer-lhes os interesses fundamentais ou impor restrições consideradas inaceitáveis à sua liberdade de ação. Para os demais, dada a reconhecida necessidade de ordenar a vida internacional, o problema era como, aceitando o objetivo geral, minimizar a falta de eqüidade implícita nas idéias defendidas pelos mais fortes, inclusive 
buscando assegurar que as normas de conduta a serem acordadas fossem respeitadas também pelos grandes.

Esse esforço de estabelecer e fazer respeitar uma codificação das normas de conduta internacional dos Estados veio a ser complicado por outras tendências da vida internacional no pós-Guerra. Por um lado, a globalização - aqui entendida no sentido amplo de aceleração do crescimento dos vínculos de interdependência mundial - tornou substantivamente mais complexo e geograficamente mais abrangente o conjunto de normas necessário para disciplinar a vida internacional. Em outras palavras, para ser eficaz o sistema normativo teria de abranger um número crescente de campos da atividade humana e ser aplicável a toda a comunidade internacional. Por outro, a enorme concentração do poder em uns poucos Estados e a crescente capacidade desses mesmos Estados de projetá-lo a grandes distâncias tornava no mínimo problemático o estabelecimento de um sistema internacional aplicável a todos. Democracia e excessiva concentração de poder convivem mal, tanto nas relações entre os Estados quanto no âmbito interno de cada um.

É uma problemática que tem importância crescente para o Brasil, cujo peso internacional tende a aumentar e cuja atual política externa se quer mais assertiva.

\section{O pós-Guerra e a ordem internacional}

Ao encerrar-se a II Guerra Mundial, o mundo estava claramente a requerer um processo de reengenharia político-econômica capaz de levantá-lo dos escombros deixados pelo conflito e de evitar, sobretudo entre as grandes potências, outros enfrentamentos bélicos que, pela evolução técnica dos meios de destruição, seriam ainda mais arrasadores do que o anterior. Com exceção dos Estados Unidos e do Canadá, o que hoje conhecemos como mundo desenvolvido estava em ruínas. As antigas grandes potências européias tinham simplesmente deixado de sê-lo: viviam da esperança de uma recuperação da antiga relevância política, que nenhuma delas poderia conseguir isoladamente, e de uma retomada da prosperidade econômica que só poderia ser alcançada com a ajuda americana. Era, além disso, um continente dividido, onde os países da parte ocidental, tanto os vitoriosos como os vencidos, se sentiam diretamente ameaçados pela União Soviética, cujas tropas já ocupavam a Europa oriental e central. As metrópoles européias de velhos e vastos impérios coloniais transoceânicos, como a Grã-Bretanha e a França, já não tinham condições de manter seus domínios, nos quais a efervescência independentista se fazia cada vez mais forte. A África e boa parte da Ásia era constituída de países que ainda não haviam conquistado a própria independência (recorde-se, exemplificativamente, que a Índia só a alcançou em 1947). Assim, o número de Estados independentes era menos de um terço do atual, mas a opinião 
pública - nas colônias, nos Estados Unidos e, em boa medida, nas próprias metrópoles - já não aceitava a perpetuação do colonialismo.

Nesse mundo onde a guerra já acarretara profundas mudanças na estrutura de poder e onde outras mais se tinham tornado inevitáveis, os Estados Unidos, maior potência militar do planeta e única grande economia que não fora destroçada (em verdade crescera) no conflito, defrontava-se com enormes desafios. Eles eram de tal magnitude que mesmo a grande potência americana não poderia enfrentá-los sozinha, apesar da sua poderosa máquina bélica e dos recursos de uma economia que respondia por algo entre um terço e a metade do produto mundial, conforme o método de cálculo utilizado. Por um lado, era preciso conter a ameaça estratégica representada pelo poderio militar e político da União Soviética, que ameaçava tornar-se a potência hegemônica na Eurásia e, portanto, um desafio direto à preeminência política americana no mundo. Por outro, era mister contrarrestar o "poder brando" de Moscou, representado pela penetração da ideologia soviética, tanto na Europa ocidental, onde vários partidos comunistas nacionais exibiam notável vigor, quanto nos movimentos nacionalistas que lutavam pela independência das colônias européias e, logicamente, tinham uma predisposição anti-ocidental.

Enfrentar essa vasta problemática significava, em última análise, reordenar o mundo. Tratava-se de reunir vencidos e vencedores do último conflito numa vasta coalisão capaz de, sob a liderança dos Estados Unidos, conter a expansão política e militar da União Soviética. Para que tal aliança tivesse condições de alcançar seus objetivos, cumpria, porém, reconstruir as economias daqueles países aliados que tinham sido devastadas pela guerra, especialmente as da Europa ocidental e do Japão. Cabia também estimular a criação de instrumentos políticos regionais capazes de assegurar que antigas animosidades - como a rivalidade franco-alemã ou, mais amplamente, a preocupação da Europa ocidental com um eventual ressurgimento do militarismo germânico - não comprometessem o adequado funcionamento da nova aliança. Mais ainda, cumpria estabelecer um quadro institucional tendente a assegurar um razoável equilíbrio entre os grandes e, entre grandes e pequenos, um grau de desequilíbrio que estes últimos pudessem aceitar sem excessivo azedume. Para tanto, era também mister encaminhar o processo de descolonização de maneira formalmente eqüitativa e que, na área econômica, as novas instituições favorecessem os interesses das economias mais avançadas, porém de maneira pouco ostensiva. E era ainda indispensável que se coibissem aquelas práticas - como o protecionismo exagerado e as desvalorizações cambiais competitivas - que, no entre-guerras, tanto haviam contribuído para a depressão e, em última análise, para os desenvolvimentos que tinham culminado na II Guerra Mundial.

O resultado de tais condicionantes foi o estabelecimento, sob a impulsão política de Washington, de um número de instituições políticas e econômicas 
internacionais que, em seu conjunto, deveriam, em tese, submeter os principais aspectos das relações entre os Estados a um grau de disciplina nunca antes experimentado.

No topo desse vasto arcabouço institucional - cujas linhas gerais ainda se mantêm - encontrava-se a Organização das Nações Unidas, "baseada no princípio da igualdade soberana de todos os seus membros", à qual caberia, entre outras coisas, "manter a paz e a segurança internacionais" e fomentar, entre as nações, relações fundadas "no respeito ao princípio da igualdade de direitos e ao da livre determinação dos povos”" Apesar de princípios e propósitos tão louváveis, as assimetrias de direitos e deveres entre os membros da Organização são sobejamente conhecidos, sobretudo no tocante aos privilégios dos membros permanentes do Conselho de Segurança. Em última análise, a Carta de São Francisco estabeleceu um sistema que, na medida em que seja respeitado, veda o uso da força contra qualquer membro permanente daquele órgão, ao mesmo tempo em que permite tal recurso contra os demais, desde que aprovado pelo Conselho por maioria qualificada e sem o veto de qualquer dos Cinco Grandes. Assim, conseguiu-se, num mesmo instrumento jurídico, proclamar a igualdade soberana de todos os membros das Nações Unidas e submetê-los à tutela de cinco dentre eles. E mais extraordinário, conseguiu-se que tal instrumento fosse assinado por todos, tutores e tutelados.

No campo econômico, foram vários os organismos criados para orientar as relações internacionais e, em parte por isso, o formato da desigualdade é formalmente menos ostensivo, mas o resultado final, especialmente para os países em desenvolvimento, não é muito distinto. Um dos motivos de tais diferenças é que, enquanto na área política interessava a Washington manter a maior concentração possível de poder em suas mãos, no campo econômico, possíveis aspirações hegemônicas tinham de ser matizadas em razão dos objetivos estratégicos da própria potência maior. Assim, a recuperação econômica da Europa ocidental e do Japão era indispensável à contenção da União Soviética. Da mesma forma, dentro do objetivo de contrarrestar o poder brando de Moscou, era necessário dar, ainda que de forma parcimoniosa, alguma satisfação às aspirações dos países em desenvolvimento. E foram justamente a recuperação econômica daquelas duas áreas e o crescimento de um certo número de países em desenvolvimento que levaram a uma considerável diluição internacional do poder econômico. Em suma, enquanto na área política a centralização do comando era fundamental, no terreno econômico uma certa difusão da prosperidade - e conseqüentemente do poder era essencial à consecução do objetivo maior de contenção da União Soviética. Tudo isso contribuiu para dar ao sistema institucional criado para a área econômica características diferentes daquelas que teriam os organismos políticos internacionais. Além disso, ainda durante a Guerra Fria, mudanças que afetaram diretamente as economias centrais - como a deterioração das contas externas 
americanas, que levou, em 1971, à inconversibilidade do dólar em ouro - e a pressão dos países em desenvolvimento conduziram a importantes modificações no quadro institucional acordado na década de 1940. Bem mais do que ocorreu formalmente na área política.

Ainda durante o conflito, a idéia já aceita por Washington e Londres era estabelecer um sistema internacional capaz de promover o movimento livre e multilateral de bens e de capital. Tratava-se de algo que favoreceria os vanguardeiros da economia mundial e evitaria o protecionismo e as desordens monetárias e cambiais subseqüentes à I Guerra Mundial. Dentro dessa orientação geral, foram criadas as instituições de Bretton Woods - o Banco Internacional de Reconstrução e Desenvolvimento (Bird) e o Fundo Monetário Internacional (FMI) - e o Acordo Geral de Tarifas e Comércio (Gatt), organismos que se complementavam e reforçavam mutuamente. Este último promoveria a progressiva liberalização do comércio internacional, através da pronta eliminação das barreiras não-tarifárias e da negociação da redução, com base em concessões recíprocas, de tarifas de importação que seriam estendidas a todas as partes contratantes através da cláusula de nação mais favorecida. Por sua vez, o FMI, garantia da estabilidade cambial, oferecia também apoio a países com dificuldades de balanço de pagamentos, desde que fizessem os ajustes econômicos consentâneos com o sistema econômico internacional acordado, isto é, desde que não recorressem a medidas protecionistas abusivas ou a desvalorizações monetárias predatórias. Ao Bird cabia a assistência econômica de sentido mais estrutural, destinada, como indicado pelo próprio nome da instituição, a promover a reconstrução e o desenvolvimento dos países que o integram.

A concordância geral quanto aos objetivos econômicos essenciais a serem perseguidos - a estabilidade cambial e a liberalização comercial - não significa, porém, ausência de divergências quanto à maneira de atingi-los. Dentro do próprio grupo dos países centrais, havia uma rivalidade entre "o velho imperialismo inglês e o emergente norte-americano para definir as novas regras de jogo do sistema financeiro internacional”2. Em essência, enquanto Londres, como os demais governos europeus, procurava meios de promover a correção de uma situação de balanço de pagamentos catastrófica sem ter de enfrentar uma aguda depressão, Washington buscava estabelecer normas que contribuíssem para a projeção do seu poder econômico. Assim, enquanto, do lado americano, o plano White propunha lançar sobre os países deficitários o ônus dos ajustes necessários para reequilibrar suas contas externas, Keynes, pelo Reino Unido, insistia numa divisão de responsabilidades com os superavitários, isto é, essencialmente os Estados Unidos. Assim, nas circunstâncias da época, a vitória da tese americana isentou Washington da necessidade de prestar contas da sua política econômica. Da mesma forma, os Estados Unidos propuseram restabelecer o ouro na sua velha posição de instrumento de reserva internacional. Como a quantidade disponível daquele metal era, porém, 
insuficiente para sustentar a desejada recuperação do comércio internacional, aceitou-se que qualquer moeda nacional, desde que conversível em ouro, poderia ser utilizada como meio de pagamento externo. Na época, entretanto, só a moeda americana preenchia tal condição, de modo que a solução encontrada em Bretton Woods transformou o dólar, na prática, em moeda de reserva obrigatória no sistema internacional.

No tocante à outra grande instituição financeira, o Bird, as divergências foram menores, dizendo respeito, sobretudo, à importância relativa a ser dada a cada um dos dois objetivos a ela atribuídos - reconstrução e desenvolvimento. Previsivelmente, os Estados Unidos e os europeus defendiam o primeiro e alguns países em desenvolvimento, o segundo.

Por sua vez, o comércio internacional passou a ser regulado pelo Gatt, que buscava promover a liberalização do comércio internacional através da eliminação de barreiras não-tarifárias, como quotas e licenças de importação, e da redução das tarifas de importação, a ser negociada por meio de concessões recíprocas e estendida a todas as partes contratantes através da cláusula de nação mais favorecida. Do ponto de vista dos países em desenvolvimento, tal esquema tinha dois defeitos graves. Por um lado, o tratamento formalmente igual dispensado a países de pesos econômicos muito distintos levava a uma clara assimetria de resultados. Por outro, a forma de negociação adotada era algo paradoxal para um organismo que pregava a liberdade do comércio internacional, pois tratava como “concessões” as medidas de liberalização a serem adotadas pelas partes contratantes. Isso levou a que fosse mais beneficiado o comércio daqueles países que, pelo seu peso econômico e comercial, tinham melhores condições de pagar pelas “concessões” dos respectivos parceiros. O resultado faz-se sentir ainda hoje, apesar das modificações feitas no texto inicial do Gatt para favorecer as economias em desenvolvimento e da substituição do Acordo Geral pela Organização Mundial de Comércio, já na década de 1990: “as tarifas aplicadas pelos países ricos às categorias de bens que as nações pobres produzem são, em média, quatro ou cinco vezes mais altas do que as incidentes sobre bens usualmente importados de outros países ricos”3.

Em suma, o quadro institucional que emergiu da II Guerra Mundial, isto é, aquilo que, pelo menos formalmente, definia na época a nova ordem mundial, proclamava a igualdade entre os Estados, mas criava mecanismos que, na realidade, tenderiam, se mantidos e respeitados, a consolidar a desigualdade. Conforme comentado acima, a disparidade entre os princípios acordados e os mecanismos institucionais estabelecidos é flagrante na área política, sobretudo no tocante ao funcionamento do Conselho de Segurança das Nações Unidas. No terreno econômico, o problema era menos de desigualdade ostensiva do que da falta de eqüidade resultante da igualdade formal aplicada a parceiros desiguais. Como diria um diplomata indiano na década de 1960, equal treatment is only equitable among equals. 
Assim, a ordem mundial proclamada ao encerrar-se o grande conflito partia de um discurso idealista, que defendia a igualdade e o direito à autodeterminação dos povos e condenava o colonialismo, para, na prática, tratar de assegurar, no dizer de Araújo Castro, o "congelamento da estrutura do poder mundial"4. Entretanto, apesar de todas as cautelas para assegurar a continuada preeminência político-econômica dos mais fortes, as mudanças da realidade internacional levaram as próprias grandes potências a abandonar muito do que elas mesmas haviam construído.

Na área política, a recuperação de economias como a alemã e a japonesa, bem como o aumento da relevância internacional de alguns países em desenvolvimento, tornaram claramente anacrônica a composição do Conselho de Segurança. Além disso, durante a Guerra Fria, o recurso ao veto recíproco pelas duas superpotências - ou a simples possibilidade do seu uso - e o aumento do número de países em desenvolvimento na Assembléia Geral levaram a um certo imobilismo e relativo desprestígio das Nações Unidas. As grandes questões internacionais continuaram a ser objeto de discussão nas instâncias da ONU, mas a organização tornou-se essencialmente o palco onde, no quadro da rivalidade entre Washington e Moscou, os países menores buscavam exercer pressão sobre os líderes de cada uma das duas grandes alianças. Assim, direta ou indiretamente, aquelas questões passaram a ser efetivamente tratadas no quadro do confronto entre os blocos liderados pelos Estados Unidos e pela União Soviética. Era esse confronto que, em última análise, definia a ordem mundial.

No terreno econômico, o edifício financeiro construído em Bretton Woods tornou-se insustentável a partir do momento em que Washington, a braços com o forte déficit das contas externas americanas, viu-se obrigado, em agosto de 1971, a suspender a conversibilidade do dólar em ouro, o que levou à desvalorização daquela moeda e ao fim do sistema de paridades fixas. Era a conseqüência inevitável da relativa difusão do poder econômico internacional: tal como originalmente concebido, o sistema de Bretton Woods só poderia subsistir num mundo em que a economia americana mantivesse o peso relativo que tinha ao término da II Guerra Mundial. Paralelamente, no Gatt, sentindo suas indústrias tradicionais ameaçadas pela competitividade do Japão e de vários países de industrialização recente, as grandes potências industriais passaram a adotar práticas protecionistas que procuravam respeitar a letra, mas certamente feriam o espírito, do Acordo Geral. Foi o caso das chamadas restrições “voluntárias” a exportações, de instrumentos como o Arranjo Multifibras ou do uso especioso de medidas antidumping, por exemplo. Por outro lado, frente à necessidade política de fazer algum gesto em relação aos países em desenvolvimento, que pressionavam por um tratamento mais eqüitativo, aceitaram mudanças nas regras originais, possibilitando a concessão de tratamento mais favorável às economias em desenvolvimento e a criação de 
um sistema geral de preferências. Na prática, os benefícios não corresponderam, porém, às expectativas dos países favorecidos.

De maneira muito menos dramática, mas não menos profunda do que ao término da II Guerra Mundial, o fim da Guerra Fria, com a implosão do bloco e posteriormente do próprio Estado soviéticos, colocou a comunidade internacional diante do desafio de repensar a ordem mundial. Talvez mais ainda do que na década de 1940, a realidade internacional da de 1990 aconselhava pensar em termos de uma continuada e abrangente regulamentação da vida internacional, política e econômica. As assimetrias da nova estrutura do poder mundial tornavam, porém, extremamente problemático pôr em prática o bom conselho.

O fim do bipolarismo político-militar, que condicionara as grandes linhas da vida internacional durante mais de quatro décadas, deixara à superpotência remanescente um tremendo desafio. Na ausência de um adversário à altura, seu imenso poderio militar passava a carecer de objetivo, a menos que optasse por usá-lo para afirmar sua autoridade sobre o resto do mundo ou por fomentar um estado de tensão internacional permanente, no qual os demais se veriam na contingência de chamá-la a exercer o papel de polícia da comunidade internacional. A primeira hipótese esbarrava, porém, numa base econômica insuficiente para sustentar, sem o apoio de outros Estados, a hegemonia política para a qual os Estados Unidos estavam militarmente equipados. Em 1991, a Guerra do Golfo ilustrou o problema. Foi uma operação liderada politicamente por Washington e executada com instrumentos bélicos dominantemente americanos, mas largamente financiada por outros países ${ }^{5}$. A segunda hipótese suscitaria implicações políticas mais amplas, a algumas das quais faremos menção adiante. Fundamentalmente, o problema é que, em contraste com a década de 1940, havia, ao término da Guerra Fria, uma enorme diferença entre a concentração do poder militar e a do econômico. Como assinala Joseph Nye, enquanto é possível falar de um mundo unipolar no campo militar, existe, no econômico, uma situação mais próxima do multipolarismo ${ }^{6}$. Na verdade, como potência militar hegemônica, os Estados Unidos sofrem hoje de uma forma peculiar de vulnerabilidade externa. Com déficits fiscal, comercial e de contas correntes de cerca de $5 \%$ do PIB $^{7}$, uma redução substancial do ingresso de capitais externos lançaria a poderosa economia americana numa forte recessão, que quase certamente comprometeria o continuado exercício de uma liderança política do mundo, pelo menos na forma autoritária como o governo Bush parece entendê-la. Uma recessão profunda nos Estados Unidos afetaria, porém, tão negativamente a economia mundial que, na medida do possível, os governos dos demais países ricos provavelmente preferirão cooperar no sentido de evitar tal desfecho. Em outras palavras, é bem possível que, politicamente, prefiram, dentro de certos limites, continuar a financiar a liderança dos Estados Unidos sobre eles mesmos. A curto e médio prazos, é uma hipótese plausível, mas sua sustentabilidade por um período maior é altamente discutível. 
No dizer de Lawrence Summers, Secretário do Tesouro no governo Clinton, “a economia mundial está voando com um só motor”, no caso, a demanda assegurada pelo mercado americano. Como assinala The Economist, "desde 1995, quase $60 \%$ do crescimento cumulativo do produto mundial tem vindo da América, quase o dobro da participação americana no PIB do mundo. Essa contribuição desproporcional para o crescimento global reflete uma extraordinária elevação de gastos nos Estados Unidos”, onde a demanda interna tem crescido, no período, a uma taxa anual média cerca de duas vezes maior que a do resto do mundo. No futuro previsível não há substitutos claros para esse papel de locomotiva da economia mundial. Existe, pois, um evidente interesse do mundo em que a economia americana não entre numa forte recessão, mas para tanto seria necessário que os Estados Unidos encontrassem meios de reduzir seus déficits fiscal e de contas correntes de maneira gradual, mas significativa, de modo a não causar excessivas turbulências na economia internacional. Alternativamente, seria preciso que o resto do mundo continuasse indefinidamente a financiar tais saldos negativos em condições sustentáveis para a economia americana e para os investidores. Por motivos que não caberia examinar aqui, a primeira hipótese é de difícil realização e a segunda, praticamente inviável. Em todo caso, o passado recente não autoriza otimismos. O orçamento americano passou de um saldo positivo de mais de $2 \%$ do PIB em 2000 para um déficit estimado em bem mais de $4 \%$ este ano, ou seja, uma deterioração de quase $7 \%$ do PIB. Na ausência de uma considerável mudança na distribuição da demanda internacional - improvável nas atuais condições das economias européia e japonesa - há estimativas de que uma significativa melhora das contas externas americanas poderia exigir uma depreciação do dólar da ordem de 40\%. E a participação dos investidores privados estrangeiros na cobertura do déficit em contas correntes americano tem caído, sendo substituídos sobretudo por bancos centrais asiáticos. ${ }^{8}$

O quadro geral que vimos examinando até aqui suscita duas grandes questões estreitamente interrelacionadas, uma econômica, outra política. A primeira é a medida em que os responsáveis pelas grandes economias mundiais - sobretudo a americana, a da União Européia e a japonesa - encontrarão a disposição e os meios de estabelecer, em condições hoje muito menos favoráveis, o tipo de coordenação econômica que permitiu, na década de 1980, sair de uma crise algo semelhante. A segunda é se Washington terá a habilidade necessária para conduzir a própria política externa de forma a liderar e encorajar tal espírito de cooperação econômica, em vez de dificultá-la com seu excessivo unilateralismo na área política. Na ausência de uma ameaça externa comum, solidariamente percebida como tal - como foi o caso da União Soviética durante a Guerra Fria - a noção do que os aliados de Washington considerariam aceitável já não é a mesma. Dentro dessa ótica, não é surpreendente que os responsáveis pela política externa americana se inclinem por encontrar uma nova ameaça externa comum - ou por criá-la. 


\section{A busca de um inimigo comum}

De um ponto de vista ocidental, a vitória sobre o império soviético teve um lado profundamente irônico: pode ter sido o fim do Ocidente, no sentido políticomilitar que a expressão adquirira durante o então chamado conflito Leste-Oeste. Esse o sentimento, filho da frustração de uma liderança abalada, que se reflete, p. ex., de forma contundente, nas primeiras linhas de um estudo recente de Robert Kagan: "Já é tempo de parar de fingir que os europeus e os norte-americanos têm a mesma visão do mundo ou que habitam o mesmo mundo. Na importantíssima questão do poder, da eficácia do poder, da moralidade do poder, da vontade de poder - as perspectivas norte-americana e européia divergem."

Com o desaparecimento da ameaça representada pelo bloco soviético, os países que integram a Otan readquiriram a capacidade de divergir do seu líder sem porem em risco a própria segurança. Assim, a liderança americana no Ocidente foi abalada pela própria vitória, e a grande aliança militar iniciou o questionamento dos seus objetivos no novo cenário internacional. Para os europeus, tal questionamento se fazia no contexto de uma certa reaquisição de autonomia, enquanto para Washington, ele ocorria numa situação paradoxal, em que a recémadquirida supremacia mundial vinha acompanhada de uma diluição de autoridade entre os seus próprios aliados. Em última análise, para seus sócios na aliança atlântica, os Estados Unidos deixaram de ser o protetor necessário para se tornarem uma espécie de primus inter pares, importante, mas já não indispensável à sobrevivência dos demais.

A nova conjuntura aconselhava Washington a adotar um novo estilo de liderança, no qual o peso da sua economia e seu incontrastável poderio militar pela relevância de ambos para o bem de uma coalisão cujos membros continuavam a ter muito em comum - poderiam ser usados como instrumentos de persuasão, mas já não de coação. E inicialmente essa parece ter sido a inclinação do governo americano, que em outubro de 1990, proclamava nas Nações Unidas sua visão de uma nova ordem mundial: “...uma nova parceria de nações que transcenda a Guerra Fria. Uma parceria baseada em consulta, cooperação e ação coletiva, especialmente através de organizações internacionais e regionais. Uma parceria unida por princípios e pelo império da lei, e apoiada numa divisão eqüitativa de custos e compromisso."10

Essa disposição inicial não resistiu, porém, às realidades da política internacional, inclusive - ou sobretudo - à relutância dos próprios Estados Unidos em pautar sua política externa "por princípios e pelo império da lei” internacional. Assim, a idéia de uma "nova ordem mundial”, inicialmente muito comentada, foi prontamente abandonada, tendo a própria expressão caído em desuso. Seguiu-se uma aparente tendência a agir seletivamente através da Otan, levando aquela organização a assumir atribuições que a Carta das Nações Unidas reserva ao 
Conselho de Segurança, como ocorreu na Iugoslávia. Às vezes, porém, fora da Europa, nem à Otan se recorria, como foi o caso do estabelecimento de zonas de exclusão aérea pelos Estados Unidos - com o concurso da Grã-Bretanha e, inicialmente, da França - no norte e no sul do Iraque, com a finalidade ostensiva de proteger os curdos e os xiitas. Era o viés unilateralista que progressivamente assumia a política externa de Washington, até então com o beneplácito das principais potências européias.

Tratava-se, entretanto, do que poderíamos chamar de unilateralismo brando, que, embora criticado, não chegava a chocar a opinião mundial e era apoiado por alguns dos principais aliados dos Estados Unidos. Em última análise, ele ainda não se distanciava muito da prática - embora não do discurso político - tradicional de Washington. Claramente não era, entretanto, a orientação preferida pelo ainda candidato George W. Bush e aqueles que se tornariam seus principais assessores em matéria de política externa. Em artigo publicado em fevereiro de 2000, Condoleezza Rice, hoje responsável por assuntos de segurança nacional na administração americana, criticava o fato de muitos nos Estados Unidos se sentirem pouco à vontade com as noções de "política de poder, grandes potências e equilíbrios de poder", atitude que, em sua forma extrema, levava a um "apelo reflexo a noções de direito e normas internacionais, e à percepção de que o apoio de muitos Estados - ou ainda melhor, de instituições como as Nações Unidas - é essencial ao exercício legítimo do poder.” Tudo isso, segundo a autora, teria levado à substituição do "interesse nacional” por "interesses humanitários” ou pelos interesses da "comunidade internacional”. Nesse sentido, faz uma crítica específica à tradição wilsoniana e à política externa do presidente Clinton, que em parte a ela se filiaria, por negligenciar os interesses americanos em sua preocupação com “o direito e as normas internacionais" 11 . O artigo era, em alguma medida, o ovo da serpente - através dele já se podia antever o sentido geral da política externa do governo Bush.

Na verdade, Washington nunca permitira que sua preocupação com o direito internacional chegasse a interferir com a defesa daquilo que percebia como o interesse nacional americano. Tinha, porém, a cautela de não adotar um discurso de poder, tratando antes de manter uma retórica coerente com os valores fundamentais da sociedade americana, o que resultava numa atitude ambivalente, na qual coexistiam o louvor aos ideais de uma sociedade democrática e o efetivo respeito à raison d'état. Os Estados Unidos foram assim, durante a Guerra Fria, os líderes e defensores do "mundo livre”, ao mesmo tempo em que promoviam e sustentavam alguns dos regimes mais opressivos e detestáveis daquela época. Em suma, as coisas freqüentemente se passavam como se a defesa da democracia nos Estados Unidos e nos demais países desenvolvidos exigisse e justificasse, frente à ameaça à liberdade representada pela União Soviética, o seu sacrifício no Terceiro Mundo. O discurso idealista permitia assim confundir a promoção do 
interesse americano com a defesa da liberdade no mundo não-soviético. Quando, portanto, Condoleezza Rice opina que a "persecução dos interesses nacionais [pelos Estados Unidos] depois da II Guerra Mundial levou a um mundo mais próspero e democrático", fica-se sem saber se ela acredita no discurso-camuflagem do passado, o que pareceria improvável. E quando ela afirma que "isto pode acontecer de novo”, fica-se em dúvida sobre se, alternativamente, ela acharia viável manter as práticas da Guerra Fria na ausência de uma forte ameaça externa. Seja como for, os atentados de 11 de setembro parecem ter sido percebidos como a oportunidade de persuadir os demais países de que estavam diante de uma ameaça exógena comparável àquela antes representada pela União Soviética. Tal ameaça, originada a nível infra-estatal, estaria sendo alimentada por alguns Estados fora da lei (a serem apontados como tais por Washington), que deveriam ser tratados como inimigos. Ainda mais importante, caberia confrontar o povo americano com o fato de que estava agora exposto a um ataque à sua própria segurança interna, algo que não ocorrera mesmo durante a Guerra Fria. Na medida em que tal interpretação dos acontecimentos fosse aceita interna e externamente, Washington recuperaria frente aos seus aliados - inclusive agora a Rússia - as vantagens políticas associadas à percepção de uma ameaça externa comum, sem a necessidade de recorrer às ambigüidades do discurso político anterior.

Num primeiro momento, a tática pareceu funcionar. Chocado com a violência efetiva e simbólica dos atentados, o mundo solidarizou-se com os Estados Unidos, parecendo inclusive tolerar sem repugnância o discurso maniqueísta do primeiro mandatário americano, que praticamente lançou um ultimato ao resto do mundo: aos demais países caberia escolher entre Washington e o terror, ser a favor ou contra os Estados Unidos, sem meio termo. O líder da maior potência democrática do mundo negava à comunidade internacional o direito democrático de divergir - de ser contra o terror sem, por isso, concordar com as opções americanas de política externa. E o mundo aquiesceu quase unanimemente, inclusive no ataque ao Afeganistão, cuja geografia intratável tornaria a operação praticamente inviável sem o concurso de países vizinhos.

Embalado pelo êxito, Washington lançou-se contra o segundo alvo, o Iraque, apontado como um Estado fora da lei, desrespeitador de resoluções do Conselho de Segurança, detentor de armas de destruição em massa e dominado por um regime ditatorial. Evidentemente, acusações semelhantes poderiam ser feitas contra países com os quais os americanos mantêm boas relações ou contra os quais, pelo menos, não pensam em agir militarmente. Mas a comunidade internacional, desperta do primeiro impulso de solidariedade incondicional, negou a Washington seu apoio e o necessário respaldo das Nações Unidas a uma operação bélica. Foi um momento decisivo da atual política externa dos Estados Unidos. Cabia-lhe escolher entre respeitar o sistema internacional e renunciar, pelo menos no imediato, à guerra contra o Iraque ou, alternativamente, proclamar o seu unilateralismo, atropelar a 
ONU e atacar, com a ajuda do Reino Unido e de quem mais decidisse desafiar igualmente o direito internacional. A opção do governo Bush foi pela segunda hipótese, chegando a declarar que a ONU se tornaria irrelevante caso não adotasse medidas de força contra Bagdá. Invertia-se dessa forma a ordem normal das coisas: em vez de a política externa de Washington ajustar-se às normas do sistema internacional, era o sistema que devia ajustar-se àquela política, sendo declarado irrelevante na medida em que assim não fizesse. Os Estados Unidos assumiram assim o que poderíamos chamar de atitude imperial, no sentido do comentário de Henry Kissinger, para quem "impérios não têm interesse em operar dentro de um sistema internacional; eles aspiram a ser o sistema internacional”" 12 .

A nova orientação de política externa só surtiria efeito, porém, na medida em que Washington continuasse a dispor de um poder militar incontrastável e que pudesse usá-lo, preventiva e seletivamente, contra Estados declarados "fora da lei”. Agir somente em reação a um ataque seria inútil, já que, como Estados, os "fora da lei” jamais atacariam os Estados Unidos. Agir contra todos eles seria inconveniente, já que, em alguns casos, tal ação poderia não ser considerada aconselhável ou oportuna, como bem ilustra o caso da Coréia do Norte. Em suma, só a liberdade de agir discricionariamente interessava a Washington. A "Estratégia de Segurança Nacional dos Estados Unidos”, enviada ao Congresso pelo Presidente Bush cerca de um ano depois dos atentados do 11 de setembro de 2001, formalizou tais objetivos, convertendo-os em política oficial do governo americano.

A meta de uma superioridade militar permanente é ostensivamente declarada: "Nossas forças serão suficientemente fortes (sic) para dissuadir potenciais adversários de buscarem um poderio militar na esperança de ultrapassarem ou igualarem o poder dos Estados Unidos”. A norma estabelecida na Carta das Nações Unidas, segundo a qual um Estado só pode usar a força contra outro em casos de legítima defesa ou por determinação do Conselho de Segurança, é explicitamente rejeitada: "Não podemos deixar nossos inimigos atacarem primeiro. (...) Defenderemos os Estados Unidos, o povo americano e nossos interesses em casa e no exterior, identificando e destruindo a ameaça antes que ela alcance nossas fronteiras.” E o unilateralismo era reafirmado: “Embora os Estados Unidos pretendam constantemente buscar o apoio da comunidade internacional, não hesitaremos em agir sozinhos se necessário.”13

A intenção não poderia ser mais clara - os Estados Unidos, para usar a frase de Kissinger, passariam a "ser o sistema internacional”.

Para fazer opção política tão ambiciosa, é de supor que os planejadores políticos de Washington tenham avaliado que possuem os meios necessários para manter indefinidamente a sua superioridade militar e recursos próprios para usála, independentemente de apoio externo. Ou alternativamente, que seus aliados se teriam convencido de que o terrorismo internacional seria de fato a ameaça global 
pintada pelo Governo Bush e, conseqüentemente, estariam dispostos, como durante a Guerra Fria, a continuar financiando a liderança dos Estados Unidos, agora sobre uma coligação de forças ainda mais ampla. Nessa última hipótese, Washington teria conseguido criar a percepção de uma ameaça externa comum, necessária à consecução dos seus objetivos. Até o momento em que escrevo, nenhuma das duas hipóteses parece, entretanto, confirmar-se.

No primeiro momento, o mundo solidarizou-se com os Estados Unidos e a existência de uma resistência armada ao governo talibã permitiu levar a bom termo a ação militar, com o emprego de efetivos americanos muito reduzidos e um número de baixas muito pequeno para a envergadura da operação. A primeira parte do empreendimento foi, pois, bem sucedida, política e militarmente. A reconstrução política, econômica e administrativa do país vem, entretanto, marcando passo.

No caso do Iraque, a situação é pior. Tendo o Conselho de Segurança se recusado a determinar uma ação militar contra Bagdá, Washington decidiu agir praticamente sozinho, tendo como único apoio significativo o do Reino Unido. A operação puramente militar foi um êxito, mas o seu lado político, econômico e administrativo beira o fiasco. As forças de "libertação" da coligação angloamericana são vistas pela população local como uma tropa de ocupação; o número de americanos mortos desde que foi declarado o encerramento das atividades bélicas é maior do que o da fase anterior; ainda não foi possível estabelecer um governo iraquiano, o que, além do impacto político negativo, inviabiliza a ajuda de agências internacionais como o Banco Mundial; o fornecimento de serviços básicos, como água e luz, continua precário; a própria representação da ONU, aparentemente associada à imagem do estrangeiro invasor, foi alvo de um ataque mortífero, no qual perderam a vida vinte e dois funcionários internacionais, entre os quais nosso compatriota Sérgio Vieira de Mello. Diante de tantos percalços e dos custos crescentes do pós-guerra (há pouco, o governo Bush pediu ao Congresso um crédito adicional de US\$ 87 bilhões para cobrir aqueles gastos), a administração americana voltou às Nações Unidas. Tenta agora um passe de prestigiação diplomática que lhe permita, sem abrir mão do controle da operação, dividir com a comunidade internacional os ônus diplomáticos e financeiros da empreitada que, contra o melhor alvitre daquela comunidade, Washington insistiu em levar avante. Até o momento em que escrevo, não foi possível negociar um texto de resolução capaz de conciliar as posições divergentes.

À luz de tais desenvolvimentos, parece que o governo Bush cometeu um erro de cálculo. Dado o peso político, econômico e militar dos Estados Unidos, trata-se, porém, de um equívoco de graves conseqüências potenciais para a comunidade internacional. Como diz Emmanuel Todd, “os Estados Unidos estão se tornando um problema para o mundo. Estávamos acostumados a ver neles uma solução."14 
Sintetizando, poderíamos, pois, dizer que:

- Até 1989, a ordem política mundial foi largamente definida pela rivalidade entre a duas superpotências, o que dava aos Estados Unidos, como baluarte do bloco ocidental, a preeminência diplomática entre os seus aliados.

- A implosão do império soviético e o conseqüente desaparecimento da ameaça externa comum deixaram Washington com um poder bélico incontrastado em âmbito mundial, mas uma liderança diplomática algo diminuída no seu próprio bloco - situação agravada pela relativa diluição do poder econômico internacional ocorrida ainda durante a Guerra Fria.

- Isso colocou os Estados Unidos frente ao dilema de aceitar uma posição de primus inter pares na comunidade internacional ou criar condições que lhe permitissem, num novo contexto mundial, restaurar sua liderança política com base em sua indiscutível hegemonia militar.

- Os atentados de 11 de setembro de 2001 pareceram oferecer a oportunidade de criar tais condições: caberia convencer o mundo especialmente, mas não apenas, os países ocidentais - de que estava diante de uma ameaça comum, e que para debelá-la cumpria seguir a liderança política e militar de Washington.

- Até o momento, a comunidade internacional, em sua ampla maioria, tem-se mostrado pouco convencida, o que cria um impasse entre ela e a maior potência econômica e militar do planeta, com desdobramentos ainda imprevisíveis para ambos.

Na área econômica, a situação é distinta, porém não mais animadora. Como já assinalado, não há aqui uma potência hegemônica, mas um grupo de países desenvolvidos que buscam promover ativamente seus interesses naqueles setores em que são mais competitivos e proteger, a expensas dos próprios consumidores e dos produtores de países em desenvolvimento, aqueles em que não o são. Embora não haja plena unidade dentro de qualquer dos lados em confronto, existe considerável convergência entre os Estados Unidos e a União Européia, de um lado, e um grupo muito expressivo de países em desenvolvimento, de outro. Isso ficou evidente no fracasso da recente reunião ministerial da Organização Mundial de Comércio, em Cancun. É possível que as conseqüências de um eventual debilitamento da OMC leve à reflexão e à genuína busca de fórmulas de conciliação, mas é igualmente possível que Bruxelas e Washington optem por priorizar os acordos bilaterais e regionais de comércio, em detrimento do sistema multilateral. O representante americano para negociações comerciais, Robert Zoellick, insinuou claramente tal possibilidade. É um risco particularmente palpável no momento em que a União Européia se concentra nos problemas ligados 
à sua ampliação para o leste da Europa e os Estados Unidos revelam significativo pendor protecionista.

Em suma, ao meditar sobre os desenvolvimentos recentes da ordem mundial, tem-se a desconfortável impressão de uma certa impaciência dos grandes com o multilateralismo e com as legítimas aspirações econômicas e políticas dos países médios. No caso de Washington, isso é particularmente perceptível na área política, onde a superioridade militar parece aguçar-lhe a consciência da própria força e a disposição de projetá-la politicamente. Paralelamente, na área econômica, a Europa nada fica a dever ao seu aliado do outro lado do Atlântico.

\section{A ordem mundial e o Brasil}

Para grandes países periféricos, como o Brasil, a ordem mundial, tal como hoje se apresenta, oferece um duplo desafio. A curto e médio prazos, como superar os obstáculos que ela coloca quotidianamente aos seus interesses. A mais longo prazo, como promover o surgimento de uma nova ordem, mais justa e democrática. São desafios particularmente evidentes no caso de um governo que se elegeu tendo como compromisso central de sua política externa "garantir uma presença soberana do Brasil no mundo"15 e, para tanto, pretende, nas palavras do nosso Ministro das Relações Exteriores, "ser muito afirmativo na busca de maior democratização das relações internacionais." 16 Tudo isso será mais viável na medida em que seja possível, na expressão do Presidente em seu discurso de posse, "estimular os incipientes elementos de multipolaridade da vida internacional contemporânea”. O problema é que tal percepção do interesse nacional nos coloca em frontal divergência não só com a atual ordem mundial, porém, mais diretamente, com a política do governo Bush, cujo objetivo parece ser a consolidação de um sistema politicamente unipolar e, portanto, de relações internacionais menos - e não mais - democráticas.

Vê-se, pois, o Brasil numa situação diplomática complexa. Demasiado grande para aceitar passivamente uma ordem mundial flagrantemente injusta e antidemocrática, mas não grande bastante para sobre ela influir direta e significativamente, tem na cooperação com países afins a única forma de responder efetivamente àqueles desafios. Essa foi a rota anunciada pelo candidato Luiz Inácio Lula da Silva, que se propôs desenvolver "um bilateralismo forte” com países como China, Índia e Rússia, bem como estabelecer com eles linhas comuns de atuação em organismos multilaterais. Da mesma forma, no âmbito continental, propõe-se fortalecer o Mercosul e, mais abrangentemente, a cooperação com os demais países sul-americanos, de modo a ter melhores condições de negociar uma possível área hemisférica de livre comércio. Não é, porém, um caminho fácil ou seguro. No âmbito multilateral, tanto a situação do Iraque, na área política, 
como, na econômica, a recente reunião ministerial da OMC, em Cancun, ilustram algumas das suas potencialidades, mas também seus limites.

Na luta política de Washington para conseguir a autorização do Conselho de Segurança para atacar o Iraque; a Alemanha, a França e a Rússia foram seus mais ativos opositores. Agora, quando os Estados Unidos - defrontados com o custo político e econômico do pós-guerra, aparentemente subestimado - pedem ajuda à comunidade internacional, Berlim e Moscou parecem mais inclinados a restabelecer a harmonia com Washington, deixando Paris relativamente isolada. É uma boa ilustração das dificuldades de manter a coesão de qualquer grupo frente aos desígnios e à capacidade de pressão de uma superpotência. No caso, o Brasil deixou clara sua discordância com a política americana, mas, não sendo membro do Conselho de Segurança, não esteve diretamente envolvido nas escaramuças multilaterais.

No caso dos países em desenvolvimento - muito mais numerosos, muitos deles economicamente dependentes de algum país desenvolvido e geralmente menos equipados para o processo negociador - a dificuldade é levá-los além do apoio a teses e reivindicações genéricas e do confronto retórico com os grandes. Transformar uma solidariedade pouco mais do que simbólica em participação efetiva num processo concreto de negociação é extremamente árduo, como tivemos ocasião de comprovar, no passado, em nossa experiência com o Grupo dos 77. Agora, na reunião de Cancun, lideramos, juntamente com China e Índia, um reduzido grupo de países em desenvolvimento, o chamado G-21. Seu objetivo precípuo era promover a liberalização do comércio internacional de produtos agrícolas e o fim dos subsídios concedidos pelos países ricos aos seus agricultores. Foi provavelmente o caráter compacto do grupo e a especificidade de suas reivindicações que lhe permitiram manter-se coeso e, na avaliação insuspeita de The Economist, "bem organizado e profissional”, “negociando ativamente tanto com a América quanto com a Europa" ${ }^{17}$. O grupo tornou-se assim, segundo o mesmo observador, uma voz poderosa na reunião. Isso não permite ignorar, porém, os problemas da cooperação operacional entre países supostamente afins. É significativo, p. ex., que o G-21 tenha contado com a participação de apenas dois países africanos (Nigéria e África do Sul). Presumivelmente, muitos dos demais estavam mais interessados em problemas específicos (subsídios americanos ao algodão, p. ex.) ou em suas preferências comerciais na União Européia, não vendo por que erodi-las através de uma eventual redução erga omnes das barreiras tarifárias na Europa. E não é certo - nem talvez desejável - que exatamente o mesmo grupo se mantenha em outras negociações.

Essas debilidades da negociação em grupo, decorrentes de limitações internas, são ainda mais relevantes na medida em que a oposição dos beneficiários da ordem atual é tenaz, às vezes brutal. Defrontado com o fracasso de Cancun, o principal negociador americano não hesitou em responsabilizar por ele os países 
em desenvolvimento e em deixar claro que os Estados Unidos têm outros recursos, como os acordos bilaterais ou regionais de comércio. A ameaça implícita era que a maior economia do mundo poderia, se contrariada em seus objetivos, reduzir seu apoio ao sistema multilateral, geralmente percebido como particularmente importante para os países em desenvolvimento, que têm menor poder de barganha. Em tudo isso há o mesmo desprezo que, na área política, Washington já manifestara pelas instâncias multilaterais, que se tornariam "irrelevantes" na medida em que não se amoldassem aos objetivos e táticas da política externa americana. A diferença é que, no campo econômico, os Estados Unidos não contam com a posição hegemônica que, em função de sua indiscutível superioridade militar, se consideram em condições de manter no terreno político. Trata-se, entretanto, de uma diferença que só limitadamente favorece os países periféricos.

O antagonismo das percepções básicas do Brasil e dos Estados Unidos no que se refere ao quadro institucional que formalmente define a ordem mundial ficou muito claro na primeira aparição do Presidente brasileiro perante a Assembléia Geral das Nações Unidas. Para o mandatário brasileiro, “o aperfeiçoamento do sistema multilateral é a contrapartida necessária do convívio democrático no interior das nações. Toda nação comprometida com a democracia no plano interno deve zelar para que, também no plano externo, os processos decisórios sejam transparentes, legítimos, representativos. As tragédias do Iraque e do Oriente Médio só encontrarão solução num quadro multilateral, em que a ONU tenha um papel central.”18 Assim, para o Brasil, o multilateralismo, menosprezado por Washington, é praticamente um dever da política externa dos países democráticos - um corolário da sua opção interna pela democracia. A solução para a situação do Iraque e a crise no Oriente Médio, que os Estados Unidos procuram encaminhar com o mínimo de interferência das Nações Unidas, tem de ser encontrada no âmbito daquele organismo. E para melhor assegurar as desejadas transparência, legitimidade e representatividade do processo decisório da própria ONU, o Presidente brasileiro defendeu o fortalecimento da Assembléia Geral, que deve inclusive "assumir suas responsabilidades na administração da paz e da segurança internacionais”. Seria o reforço do órgão mais democrático da ONU frente àquele mais oligárquico, que hoje é o Conselho de Segurança. Da mesma forma, segundo o Presidente brasileiro, cabe "devolver ao Conselho Econômico e Social o papel que lhe foi atribuído pelos fundadores da organização”, que assim poderá “participar ativamente da construção de uma ordem econômica mundial mais justa.”

Paralelamente a essas escaramuças em torno de questões multilaterais de alcance mundial, o Brasil, na mesma linha de entendimento com países presumivelmente afins, trata de fortalecer os laços de cooperação e de integração econômica com os demais Estados sul-americanos. É uma linha estratégica intrinsecamente importante para a nossa política regional, mas também para as negociações da Alca e para a nossa aspiração de integrar, como membro 
permanente, um Conselho de Segurança das Nações Unidas ampliado. Nos dois últimos casos, a percepção de uma suposta afinidade regional de interesses pode, entretanto, provar-se apenas parcialmente válida. No tocante à Alca, alguns governos do continente, inclusive do Mercosul, já deixaram clara sua preferência por acordos bilaterais com os Estados Unidos, o que tende a debilitar nossa base de atuação diplomática frente a Washington, como se viu na recente reunião de Trinidad e Tobago. Isso é particularmente sério no momento em que os Estados Unidos acenam com a possibilidade de priorizarem os acordos regionais e bilaterais. No que se refere à reforma do Conselho de Segurança, teríamos de atentar para a posição do conjunto da América Latina, e não apenas da América do Sul. E em distintas ocasiões, os dois outros grandes países da região, Argentina e México este último ainda bem recentemente -, já deixaram claro que não favorecem a escolha do Brasil como membro permanente daquele órgão da ONU. Se tais rivalidades regionais não puderem ser superadas, iremos defrontar-nos com sérias dificuldades na nossa aspiração a um lugar permanente naquele Conselho.

Assim, tanto no âmbito mundial como no regional, a coordenação operacional com países afins oferece importantes possibilidades, como demonstrado em Cancun, mas também consideráveis limitações, ligadas tanto à dificuldade de conciliar ou contornar divergências dentro do grupo como a diferenças na disposição de cada um para resistir a pressões externas. Tais limitações tornam ineficazes os grandes blocos constituídos para a defesa de objetivos amplos e imprecisos, como, p. ex., uma nova ordem econômica mundial ou um sistema internacional mais justo e democrático. Blocos dessa natureza poderiam, pelo seu número, dar uma impressão ilusória de força, mas contribuiriam para um clima inútil de confrontação e seriam operacionalmente ineficazes. Em contraste, será útil, dentro de grupos reduzidos de países setorialmente significativos, a cooperação em prol de objetivos precisos e limitados, mas que possam contribuir para a consecução do objetivo último de melhoria da ordem mundial. Em certo sentido, foi o que se tratou de fazer na reunião ministerial da OMC, em Cancún.

\section{Sumário e conclusões}

- O século XX viu o surgimento de algo que, pela primeira vez, se poderia denominar com propriedade de ordem mundial, no sentido de um balizamento geográfica e substantivamente abrangente da conduta externa dos Estados.

- Tal abrangência não significa, porém, necessariamente participação adequada de toda a comunidade internacional na ordem estabelecida nem repartição eqüitativa dos benefícios dela decorrentes.

- Assim, ao término da II Guerra Mundial, quando o esforço de disciplinamento das relações políticas e econômicas internacionais 
tomou particular impulso, criou-se, sob a liderança dos Estados Unidos, um sistema normativo-institucional cujo funcionamento - tanto na área política como na econômica - favorecia um número limitado de países mais fortes.

- No terreno político, o sistema então criado, embora proclamando-se baseado na igualdade dos Estados, estabelecia claramente a oligarquia dos membros permanentes do Conselho de Segurança da ONU. A ordem originalmente estabelecida sofreu poucas alterações formais, porém as modificações na estrutura do poder mundial diminuíram-lhe a relevância prática. A ordem política mundial passou a ser determinada sobretudo pela rivalidade entre Washington e Moscou. O bipolarismo tornou-se mais relevante do que o multilateralismo.

- Na área econômica, a assimetria formal de poder era menos ostensiva, mas os resultados práticos do funcionamento do sistema não eram mais justos ou eqüitativos do que no campo político. As modificações introduzidas no sistema inicial - bem mais significativas do que as ocorridas nos organismos políticos - podem ser, quase todas, agrupadas em duas categorias com objetivos antagônicos. A primeira era a daquelas que visavam a dar alguma satisfação às reivindicações dos países em desenvolvimento, sem erodir a posição preeminente de que efetivamente gozavam os países centrais. A segunda, ao contrário, era a daquelas destinadas a proteger setores menos competitivos nos países industrializados ou a promover ativamente os interesses desses países em áreas de especial relevância para eles, como investimentos, propriedade intelectual e serviços.

- O fim da Guerra Fria teve um duplo efeito sobre a ordem mundial. Por um lado, guindou os Estados Unidos à posição de única superpotência, política e militarmente hegemônica. Por outro, ao eliminar a grande ameaça externa que pesava sobre o bloco ocidental, enfraqueceu a coesão daquilo que fora a aliança anti-soviética e a liderança de Washington entre seus próprios aliados. Para estes, tornara-se mais fácil discordar do líder sem pôr em risco a própria segurança.

- Para os Estados Unidos, colocou-se o dilema de resignar-se à posição de primus inter pares dentro da antiga aliança político-militar ocidental ou de procurar manter uma posição de hegemonia política, com base em seu incontestável poderio militar. A primeira opção teria de passar por um reforço do multilateralismo, com a necessária reforma das instituições políticas internacionais, de modo a adaptá-las à atual estrutura internacional de poder. A segunda levaria a mais um dilema. Por um lado, na ausência de uma clara ameaça externa comum, o apoio dos aliados tornara-se mais incerto, sobretudo no caso de 
empreendimentos militares decididos por Washington. Por outro, o exercício solitário da hegemonia, além de desvantagens políticas evidentes, defronta-se com cerceamentos econômicos, como ilustrado pela Guerra do Golfo, em 1991, e pelos desenvolvimentos mais recentes no Iraque.

- Apesar de tais dificuldades, a atual administração americana, nada inclinada ao multilateralismo, optou pela segunda hipótese. Ela era, porém, de difícil sustentação sem uma ameaça externa comum que restituísse a Washington o tipo de liderança política que exercera durante a Guerra Fria. Os atentados de 11 de setembro de 2001 foram, pois, apresentados à opinião americana e mundial como a evidência de que a comunidade internacional estava novamente colocada diante de uma tal ameaça.

- Ao primeiro momento de solidariedade, que permitiu o ataque ao Afeganistão, seguiu-se, entretanto, o ceticismo da maioria da opinião mundial quando se tratou da guerra contra o Iraque. E a oposição à política americana só fez aumentar quando os Estados Unidos atropelaram o direito internacional, declararam a ONU irrelevante e foram à guerra contra a opinião dominante no Conselho de Segurança. Apesar de tal oposição, a ordem internacional passara, na prática, a ser a ordem de Washington.

- É um estado de coisas particularmente difícil para os grandes países periféricos, entre os quais o Brasil. No nosso caso, um governo comprometido com uma política externa assertiva e com a luta por uma ordem internacional mais justa e democrática, mas sem a capacidade de, sozinho, influenciar significativamente o sistema vigente, enfrenta uma situação complexa: a orientação correta que se traçou, de defesa do interesse nacional, coloca-o em divergência estratégica com a ordem dominante e, mais especificamente, com a política da atual administração americana.

- Isso leva à necessidade de desenvolvermos uma ampla atividade diplomática, com vistas a criarmos fortes vínculos bilaterais com países afins e a estabelecermos com eles, em distintas áreas, estreita coordenação em organismos multilaterais. As dificuldades de toda negociação em grupo, inclusive as divergências inevitáveis mesmo entre países ditos afins, desaconselham, entretanto, a formação de qualquer bloco amplo, de composição uniforme, na defesa de alguma causa abrangente e de definição imprecisa. Trata-se antes de, para casos diferentes, organizar grupos distintos, relativamente pequenos, de países setorialmente significativos, para promover interesses limitados e bem 
definidos. Foi o que fizemos, p. ex., na recente reunião ministerial da OMC, em Cancún.

- Em certo sentido, é também o que estamos tentando fazer na América do Sul, tratando de fortalecer o Mercosul e de criar novos vínculos com os demais países da região, com vistas às negociações da Alca. Aqui se mesclam, porém, considerações bilaterais, regionais sulamericanas e continentais, as quais, por sua vez, se ligam à problemática multilateral da OMC. A recente reunião em Trinidad e Tobago, no quadro das negociações da Alca, onde os latino-americanos e mesmo os sul-americanos se dividiram, deixou clara a dificuldade da negociação em grupo, sobretudo frente a uma superpotência. Esse é um desafio de longo prazo, com o qual teremos de conviver.

Outubro de 2003

\section{Notas}

1 Carta das Nações Unidas, arts. 1 e 2.

2 LICHTENSTEJN, Samuel e BAER, Mônica. Fundo Monetário Internacional e Banco Mundial - estratégias e políticas do poder financeiro. Editora Brasiliense, São Paulo, 1987.

3 The Economist, 6 de setembro de 2003, pág. 61. Tradução minha.

4 ARAÚJO CASTRO, J. A. de. Relações Brasil-Estados Unidos da América à luz da problemática mundial. Exposição aos estagiários da Escola Superior de Guerra, em 22/6/ 1974, mimeo.

5 A guerra teria custado cerca de US\$76 bilhões, dos quais os Estados Unidos teriam arcado com aproximadamente $12 \%$, a Arábia Saudita com 29\%, o Kuwait com 26\%, a Alemanha com 16\%, o Japão com 10\% e os Emirados Árabes Unidos com 7\%. O Globo, 31/12/2002, pág. 26. V. NYE Jr., Joseph. O Paradoxo do Poder Americano - por que a única superpotência do mundo não pode prosseguir isolada. Tradução de Luiz Antônio Oliveira de Araújo, Editora Unesp, 2002.

7 Segundo dados de The Economist (13/9/2003, pág. 97), o déficit comercial dos doze meses até junho último foi de US\$529,6 bilhões; o de contas correntes é estimado, para este ano, em 5,2\% do PIB, com previsão de aumento em 2004; o orçamentário, também para este ano, é estimado pela OCDE em 4,6\%.

8 As citações e dados contidos nesse parágrafo são de “A survey of the world economy”, publicado em The Economist, 20/9/2003.

9 KAGAN, Robert. Do paraíso e do poder: os Estados Unidos e a Europa na nova ordem mundial. Tradução de Jussara Simões, Rio de Janeiro, Rocco, 2003, pág. 7.

10 Presidente George Bush, “The U. N.: World Parliament of Peace”, discurso perante a Assembléia Geral das Nações Unidas, 1 de outubro de 1990, citado em KISSINGER, Henry. Diplomacy. Simon \& Schuster, Nova York, 1994, pág. 804-5. Tradução minha.

11 V. RICE, Condoleezza. Promoting the National Interest. Foreign Affairs. January/February 2000, pág. 47.

12 KISSINGER, Henry. Diplomacy. Simon \& Schuster, New York, 1994, pág. 21.

13 Jornal do Brasil. 21/9/2002, pág. 33.

14 TODD, Emmanuel. Depois do Império. Rio de Janeiro, Editora Record, 2003, pág. 9.

15 Carta Internacional, no. 114, ano X, agosto de 2002, pág. 9. 
16 Gazeta Mercantil, 16/12/2002, pág. A-5.

17 The Economist, 20/9/2003, págs. 27 e 28. Tradução minha.

18 Discurso do Presidente Luiz Inácio Lula da Silva na abertura da 58a. Assembléia Geral da ONU. O Globo, 24/9/2003, pág. 8.

\section{Resumo}

O artigo examina o surgimento de uma ordem mundial, sobretudo a partir do fim da II Guerra Mundial, e o seu caráter antidemocrático e pouco eqüitativo. Detém-se na tendência ao exacerbamento de tais aspectos, em função do viés unilateralista assumido pela política externa do governo Bush, que busca passar à opinião interna e externa a percepção de que o mundo se encontra diante de uma ameaça global algo semelhante àquela antes representada pela União Soviética. Conclui com algumas considerações sobre o desafio que tal situação coloca para a atual política externa brasileira.

\section{Abstract}

The article examines the establishment, especially after the II World War, of an undemocratic and not very equitable world order. In the author's view, such features tend to become more severe as a result of present American foreign policy, which does not favor consultation nor respects the rules of multilateral organizations, but prefers to demand international support for its political and military decisions. This would be necessary to cope with the common threat of international terror. The article ends with some considerations on the challenge that such situation poses to Brazilian foreign policy.

Palavras-chave: Ordem Mundial; Política Externa Americana; Política Externa Brasileira.

Keywords: World Order; American Foreign Policy; Brazilian Foreign Policy. 